\title{
Landscapes of Disappearance
}

Edwin Culp

This is an original manuscript / preprint of an article published by Taylor \& Francis in Performance Research on 17 February 2020 available online: http://www.tandfonline.com/ 10.1080/13528165.2019.1717860. Please refer and quote the published article.

\author{
Abstract \\ I analyze the strategies used in Patricio Guzman's Nostalgia for the Light (Nostalgia de \\ la luz 2010), Enrique Buchichio's Behind the Truth (Zanahoria 2014) and Nicolas \\ Pereda's Summer of Goliath (Verano de Goliath 2010) to expose the political uses of \\ landscape images in concealing and reconstructing forced disappearances and the \\ violence surrounding them. I set these films against 19th century paintings by Jose \\ Maria Velasco in Mexico, Alejandro Ciccarelli in Chile, Ricardo Borrero in Colombia and \\ Juan Manuel Blanes in Uruguay, which present the territories of the young nations \\ stripped from the struggles and the heroes that brought them to independence; and are \\ instead tamed by the gaze of the painter, showing their land as ready to be exploited. \\ Their contrast makes for a montage of the ways territory, extraction and repressive \\ violence has crossed Latin American history for the last 150 years.
}




\section{Imagining disappearance}

I propose to critically reflect on the relation of violence and landscape images in Latin America, particularly through questioning its role in forced disappearance. I argue that landscape images obscure and conceal the violence and tensions over a territory, while they are frequently the only evidence of that violence. It is an image that contains violence while trying not to show it. By recurring to a montage of en plein air landscape paintings from the late nineteenth century with recent films that expose the relationship of landscape, violence and disappearance, I critically reflect on the ways in which the landscape has been used as a system to homogenize the territory in both the liberal and neoliberal eras.

In Images in Spite of All, Georges Didi-Huberman recounts an argument with Claude Lanzmann, and two close collaborators, about the possibility that the image still has to account for the violence of the Shoah. Lanzmann's nine-and-a-half-hour film makes use of interviews and testimonies to recount the event without recurring to archive images. Didi-Huberman rebates that the image has an inevitable persistence to account for, even with that which it has been incapable of registering. As a counterexample to Lanzmann, he presents Godard's Histoire(s) du Cinéma (1989-1999), who argues that every image speaks about the Shoah. He also presents a series of images, found decades later, taken and kept secret from a point of view as close as possible to the gas chambers. But he also discusses the contradiction posed by Lanzmann's use of film to show the insufficiency of the image. The testimonies on the film are embodied in the speaker's gestures, their faces evoke the events, but, also in the ruined landscapes of concentration camps deliberately destroyed; the forests that have grown where only the foundations are left. Didi-Huberman insists that an effort to imagine must be made, to hold the image in spite of all.

Over the last 50 years, the desaparecido has emerged as a figure of violence and repression across Latin American nations; particularly those undergoing a neoliberal process. More subtle and surreptitious than other violent acts, forced disappearance 
empties the experience from a commonality that could be shared or assumed collectively. Faltan cuerpos is heard in demonstrations claiming the missing bodies all over the region. On the other end, mass clandestine graves keep emerging. But the corpses found there are not enough to cover for the missing bodies; human remains have been moved around, and they are often found incomplete. If the perverse logic of extermination has to carefully consider the places where the executions will be held the camp—and the way those places will be hidden, forced disappearance is founded on a process of delocalization: disappearance can happen anywhere, the remains of a single body -if ever found-, could appear scattered in different places.

It is debatable whether forced disappearance is a Latin American invention -the Nacht und Nebel (Night and Fog) nazi operation could well be a predecessor-, but the way it was woven with right-wing and U.S.-supported authoritarian governments, as well as a neoliberal ascent in the region, was unprecedented, annulling leftist movements and any resistance to privatization or so-called modernization projects (McSherry 2002). Forced disappearances would not only aim at ideological dissents but also at those who would attempt to resist new extractivist projects or the free flow of goods - be it legal or not, in an economic system that profits from going from one to the other (Mastrogiovanni 2016). And this is not a practice that ended with the return to democracy, but that has rather been extended through other sources of repressive violence, becoming central to the preservation of economic imperatives and profit -well beyond legality.

In place of the missing body, media tend to show landscape images, often revealing the site of a clandestine grave. What becomes evident with the continuous discovery of new clandestine graves is that almost any landscape in Latin America could enclose one. The landscape image becomes a fragmentary and incomplete document, not only of the missing bodies but of the impossibility to reconstruct their experience; the image emerges as superficial, dispossessed of its relationship to the space it depicts. In this turn to the surface of the image, the fragments and pieces are placed next to each other, not trying to devise a coherent and verifiable narrative of the violent event, but rather displaying its impossibility to give account and reconstruct the events referred in them. 
'There were things to see,' insists Didi-Huberman in relation to the Shoah (DidiHuberman 2008, 61). It is not so much about finding a just image, the precise evidence that would bring justice, but insist on the existing images, to look at them again, in order to account for, or imagine, what has happened. As with Godard, the search for the just image - une image juste- comes to the realization that what we have are just images - juste des images - nothing more (Godard 2013). It is unsettling to see that, beyond the mass graves, before its encounter, a landscape is erected; its calmness seems to say nothing, to testify in silence. To insist on the images of Latin American landscapes, to go back to the dispositif that arranges the territory from an elevated point of view, to look deeply into its details as if they were traces of violence and forced disappearance, and to intertwine the imagination in the voids between the disappeared, the grave and its landscape become necessary and just gestures. Imagination is turned into a political and ethical tool: 'Imagination doesn't give an event "proportionality." It works at the very heart of the disproportion between the experience and its narrative. ... As though the imagination were animated precisely by the arrival of the "unimaginable"' (DidiHuberman 2008, 161-162).

When faced with images of clandestine mass graves in the media, it becomes inevitable to ask not only how that grave was possible, but how is it that nobody had noticed it was there, how we can distinguish it from the rest. A landscape organizes our view of the territory, setting a distance from our gaze to the ground, establishing a surface from which to approach the territory. A critique of media images - and their constant need to become evidence of the violence exerted - that does not relinquish the image can make use of this superficial quality of landscape images. Such strategies can be found in the films Nostalgia for the Light (Nostalgia de la luz, Dir. Patricio Guzman 2010), Behind the Truth (Zanahoria, Dir. Enrique Buchichio 2014) and Summer of Goliath (EI verano de Goliath, Dir. Nicolas Pereda 2010). Instead of looking for the causes of violence in the depths of the ground, these films keep landscapes in the superficial, abandoning casual relationships between the image and the event it refers, the experience and its narrative. They make use of contiguity, analogy, repetition, deceit and falsehood in those times when the image is incapable to denounce, in the unimaginable violence. Rather than looking for an image that would contain the violence 
—and perhaps making an apology of it-, they remain on the surface to make a demand for imagination.

Before moving on to the films, I propose to consider a particular moment of Latin American painting, when the modern use of landscape images became widespread across the region. With this, I do not pretend to do a historical review of the evolution of landscape images in the region, but rather to set side by side the calm and wellorganized territories of landscape painting -in the wake of the political economy of liberalism-, with the strategies taken by the films to generate a critique on the uses of landscape images in the neoliberal distribution of territories.

\section{To look from afar: landscapes without bodies}

The artistic production of the late nineteenth and early twentieth century in Latin America is marked by two parallel processes: the formation and consolidation of art academies and a growing number of landscape images. As if there was an imperative need to display a certain view of the nation: a virgin territory, ready to be explored, a rediscovery made through the use of perspective and its ordering in foregrounds and backgrounds. A new imaginary of the territory is founded: a single and homogeneous land, emancipated of its colonial ties.

We are far from the heroic narratives of war scenes, from the struggles of the nations' founders or from glorifying religious passages; this new visuality no longer depicts foreign aristocrats and their local representatives, or the divisions of caste paintings that so convincingly forged the colonial imaginaries. Landscape paintings have no defined characters, each one is treated equally by the ordering sight of the painter, the gaze is free to wander the land made available to the eyes. A point of view centers and arranges the territory with scientific proportions, visual ownership of the territory that leaves no place for resistances, subversions or differences. Thus, these painters/explorers/travelers/scientists are distanced from the city, they contextualize it from the top of a hill to present the geographical accidents that delimit it. Or they trace the horizon in the plains where men tame horses, observe their surroundings or just 
drink some mate, fusing their contemplation with the landscape. Or they can depict a group of trees, perhaps a cabin in a desolate setting. From here, the conflicts of the city, the fights for the land, the displacements of peoples and peasant work is insignificant and remote. All there is to see is a possibility on the territory from a dominant and disaffected gaze, the visual discourse of the liberal subject.

Painters such as Jose Maria Velasco in Mexico, Alejandro Ciccarelli in Chile, Ricardo Borrero in Colombia or Juan Manuel Blanes in Uruguay, would shape a school across Latin American painting, which would actually come at a much later time than in more industrialized countries. These landscapes reflect the modern need to organize and control the land, with both a pictorial and scientific visual discourse.

The arrival of the train, rapidly remote territories, accounts for an economic conquest over the political independence gained by most of the countries earlier in the century. Nature is organized by the landscape, made uniform: en plein air painters carefully detail mountains and valleys, rivers and villages, to shape everything in his horizon into a perfectly composed whole. What used to be barbaric, now looked adventurous and exploitable.

If maps and cartography were essential devices in defining, demarcating and negotiating colonial territories, the point of view of landscapes of the late nineteenth and early twentieth century display the territory not through its limits, but as a horizon for the gaze. The point of view, many times distorted to improve composition, stood as a new way to imagine and dispose of the terrain, framed in scientific positivism and the desire to explore unknown, exotic and rich places. Landscapes would turn the emancipated nations into virgin territories, ready to be exploited, as González-Stephan mentions:

Following the Industrial Revolution, the new imperial powers of the nineteenth century needed to reinvent America ideologically. America was recreated as a landscape, as an object of various discourses and disciplines, and above all as a source of wealth and resources. ... The insistence of travelers and scientists upon re-converting American lands into 'nature'-that is, lands without history, or with only a 'prehistory' in ruins - kept pace with the growth in foreign investments in these latitudes. Suddenly America's historicity could vanish in order to appear 'virgin' to Western eyes. $(2009,109)$ 
This resetting of the emancipated territories of former colonies, naturalization that stripped them of their violent history, coincided with the transformation of the political determination of territory towards its economic usage in liberalism. There would not be any more rights of way as the train could make goods cross the nation at a previously unseen speed. Preserving traditional, indigenous and sacred determinations of land would be dismissed for economic utility. The liberal subject is only limited by his horizons, driven by the desire of progress and advancement. Individual interests, and not state reason, would take the center point as the way of reaching prosperity (de Beistegui 2018, 39-40). And the landscapes were there, laying the terrain with a perspective that is drawn from the individual's point of view.

Nineteenth-century Latin American landscapes present a calmness that is almost disquieting, even ominous. This disaffection and naturalization of the territory, the scientific and faithful approach to its presentation, dissolve political interests and divides. Historical scenes of struggle, and their almost inherent violence, of seventeenth- and eighteenth-century colonial paintings, have been abandoned in favor of these homogenous, calm, bucolic and deserted spaces that depict an idyllic territory, an unlimited horizon that subdues the processes that brought it about. As if the mountains, trees, rivers, animals and characters had been painted over the corpses that we cannot see, producing a neutral surface that has lost its depth. Neutralization of political difference in favor of a more rational arrangement of the space: the laws of economics - but also of perspective - that favor its better usage and profitability. This neutral and rational imagery, with its natural economic and depoliticized laws, is being set forth by the liberal project. But the landscape is not the territory, nor its faithful scientific representation is devoid of politics; these images construct a specific imaginary, a surface of neutralization and homogeneity - a disquieting calmness - that excludes conflict.

\section{Too close, too far: disjointing the neoliberal landscape}

The late nineteenth- and early twentieth-century landscapes accounted for the 
homogenization of the natural setting through the dispositif of academic perspective, while leaving out subjects, identifiable characters and bodies, to present a virgin but ordered nature, a developing nation approaching progress and ready for foreign industrial investment. Almost a century later, the economic ethos installed by neoliberalism would be brutally realized in Latin America. From Chile as the laboratory of the new economic policies and repressive methods to Mexico, with its migration and the current state of violence, Latin American countries have been subjected to an economic rationale that has permeated every aspect of life. Regardless of the political orientation of the countries, authoritarian dictatorships first and financial capitalism later have secured the adoption of neoliberal policies across the region. And their impact can be felt on the precarization of work, formal or informal restrictions to transit across a certain space - be it due to national borders or the threat of violence-, or in the vulnerability of lives that resist these processes in any way.

Recent Latin American films question landscape production as a pacifying and homogenizing strategy. Instead of using images of violence to tear apart the calmness of the landscape or finding evidence of its deceit, they insist on the landscape images as a trace of the mechanisms used to conceal that violence. Activist and denunciation cinema tends to be critical of landscape images and their neutrality in favor of showing the people and their actions changing the state of things.

The films by Guzman, Buchichio and Pereda show that by trying to efface the violence exerted against the resistance to economic profit, landscape images become the very evidence of the effacement. They do not renounce to the landscape as if it were a fraudulent veil that would have to be ripped open to find the truth, they rather insist on the superficial quality of the landscape and produce their critique from that surface and their tensions.

In Nostalgia for the Light, Patricio Guzman uses documentary to portray the unstoppable search of a group of women to find the remains of their children that could have been fragmented and thrown in the Atacama desert. There, in the driest place on Earth and also the region with the largest number of astronomical observatories, Guzman builds a parallel relation between the mothers looking for their children on the ground and the telescopes pointing at the sky. Without renouncing to the landscape, the 
film proposes a radical change in the relationship of distance that it established: that apparently disaffected and natural look from afar, where the perspective is opened towards the horizon. On the one hand, astronomers are looking at the most distant landscapes of the cosmos, on the other, women are closely looking at the ground, walking bent forward, and reducing the landscape to the small piece of land they are examining; both too close and too far for the landscape to be neutral. Through a voiceover, Guzman presents the irony: the most powerful telescopes in the world point to the stars looking for stardust and not towards the desert to find the remains in the sand. The calm Atacama mirrors the calmness of the stars, the closeness to the grains of sand and the distance to the stars are both indifferent to humans. The film disarticulates the deserted landscape and its scientific conquest by recurring to the mechanism of similitude by emulation, where the surface of cosmos would leave an imprint on the surface of the desert (Foucault 2002, 21-22). The film can be set side by side with the documentary The Pearl Button (Botón de Nácar, 2015); in it, Guzman moves by contiguity montage from the sea to the map of Chile, to a button, to the stars, to body painting. Both films have an ethnographic quality to them, where Guzman's voiceover comments and annotates what is seen on screen, and at times it even goes as far as a tone that reminds us of television scientific documentaries.

Behind the Truth is a fiction film that goes back to the Uruguayan 'Operation Carrot': in the early days of the return to democracy, clandestine mass graves were exhumed by the military involved with the dictatorship, to move the corpses and make them disappear permanently. There are elements to think that, in order to make them harder to find, the bodies were buried vertically, like carrots. It has been much contested whether or not this operation had actually taken place, as much false information has circulated around it, becoming almost impossible to discriminate evidence (López Mazz 2015; Delgado Gerez 2014). The film takes the premise of the classic thriller All the President's Men (Dir. Alan Sekula 1979) as a starting point: two journalists following an informant to reach a truth that would shatter the political system. The Uruguayan journalists follow their own deep throat, except this one has forged the evidence to extort the journalists. False clues and modified landscapes take the protagonists further away from attaining any truth whatsoever. The search for the corpses buried standing 
becomes an obsession for the characters, who end up taking the landscape conveyed by the forger, even knowing it was false, as a possible scenario. In the film, it is not only the landscape that becomes a forgery, but the actual event may also be false: a double process of falsification. Instead of a landscape being faithful to the land it represents, here it is the land that is shaped by the projected landscape. Any clue or trace can be false, the land is susceptible to having been moved, the landscape can hide a grave. Buchichio has mentioned that it was a challenge to choose the locations for the shooting, as the crew wanted a place that was not specifically recognizable, but that seemed familiar enough (Buchichio and Culp 2018). Even then, what remains are the missing bodies and a chain of false events and places. The only way to recuperate them, it seems, would be to excavate it all, to remove the entire surface of the ground. Nicolas Pereda uses a loosely constructed fiction to saturate the landscape with the affections of the characters in Summer of Goliath. The film starts by setting up a context of violence that has permeated everyday life through a series of loosely-related scenes that happen in the same town. Through an accumulative montage, it establishes a complex narrative where a situation that a character is going through sometimes resonates and develops or it is repeated with a different character, the affection accumulated is overflown unto the next scene. It begins with the interview of a group of children and a young teenager that describe how the teenager got the nickname 'Goliath', after allegedly killing his girlfriend. A soldier returns home after being discharged, through paths and roads that take him deeper into the densely vegetated town. Teresa, his mother, keeps trying to find his father, but his whereabouts are unknown; she had the idea that he left her for another woman, or perhaps a man. The former soldier later talks to a taxi driver that narrates his migration process to the U.S. and how he told his wife he was leaving her. We subtly see the actors go in and out of their character, sometimes using short on-camera rehearsals as another way to repeat a sequence. When in movement, the camera sets the characters in the center of the frame with a short depth of field, following them closely behind, across the densely vegetated terrains; there is no way to see what is coming and orientation is impossible. We have gone too deep into the grounds and there is no horizon for our sight to control. Exuberant nature is all around, saturating the image, and the body is defenceless, 
vulnerable to the violence that has settled in the surroundings. The film is actually unclear on what happened to the father and how he went missing. But the context of violence presented, where the military and the police do nothing to help the victims and are often part of the perpetrators, sets the ground for the vulnerability that precedes the randomized structure of forced disappearance in places like Mexico, where unconcealed violence has generated an even more brutal relationship with profit and power acquisition and a disdain for life. The film ends with Teresa at sundown, fully dressed, crawling inside the river, moaning in pain. It is difficult to make out her movements through the darkness of the shot and the thicket. Her lament saturates the frame. This is not nostalgic pain, it comes from elsewhere. The affections that have passed from one character to another through a series of repetitions are now overflown unto the landscape.

By insisting on the landscape images, these films propose a set of critical strategies that dislocate the disaffected distance of the nineteenth-century painters: establishing a montage between the closest and the farthest images, distrusting not only the landscape but the land and its conformation, or immersing into the natural setup, where the landscape and the bodies imprint each other with their affections. The films also expose the strategies used in forced disappearance: from the fragmentation of bodily parts and further scattering on the desert, to the modification of landmarks to construct false evidence, and the vulneration of the bodies in the ominous setups the landscape conceals.

\section{Disappear in the landscape}

Finding the forcibly disappeared, recounting their experiences, is imperative for memory and justice in Latin America. But such is dismantling the representation system that has concealed them, provided false evidence, and positioned a discourse in favor of profitable exploitation of land and the vulnerability of those who resist. To insist on the landscape image is to accept it as the only ever-present piece of evidence, at the same time it obscures and hides proof; it is an image that contains violence while trying not to show it. The landscape image becomes a fragmentary and incomplete document, not only of the missing bodies but of the impossibility to reconstruct their experience. 
Landscape images emerge as superficial, dispossessed of their relationship to the territory they depict. In this turn to the surface of the image, the fragments and pieces are placed together, not trying to devise a coherent and verifiable narrative of the violent event, but rather displaying its concealment and the impossibility to give account and reconstruct the events referred in them.

The landscape shapes the surface of the territory that forensics will need to excavate. To embrace the superficial condition of the landscape over its more profound dimension, means to assume that truth is not always attainable, and that falseness can also be valuable for justice. In liquid compounds such as water, the surface presents a series of tensions that are very different from their interior. To think of the superficial quality of the images is to put emphasis on its interactions with other surfaces -other images, documents, bodies, territories-, rather than reduce the image to a stand-in of a missing object. When violence has reduced experience to shreds and tears that cannot be reconstructed, we need to insist on the image —even if it is just an image.

\section{References}

Buchichio, Enrique \& Culp, Edwin (2018) Paisajes de la desaparición: Zanahoria (2014). Investigación creativa en las escuelas de cine. Congreso CIBA 2018, de Beistegui, Miguel. (2018) The Government of Desire: A Genealogy of the Liberal Subject. The University of Chicago Press, Chicago; London.

Delgado Gerez, Mario (2014) 'La Operación Zanahoria no existió'. Diario La República, Didi-Huberman, Georges. (2008) Images in Spite of All: Four Photographs from Auschwitz. The University of Chicago Press, Chicago.

Foucault, Michel. (2002) The Order of Things: An Archaeology of the Human Sciences.

Routledge, London.

Godard, Jean-Luc. (2013) Historia(s) del cine. Caja Negra, Buenos Aires.

González-Stephan, Beatriz (2009) Forms of Historic Imagination. Visual Culture, Historiography, and the Tropes of War in Nineteenth-Century Venezuela. In Building Nineteenth-century Latin America. Re-rooted Cultures, Identities, and Nations, (Eds, 
Gonzalez Espitia, Juan Carlos \& Acree, William G) Vanderbilt University Press, Nashville,

López Mazz, José (2015) The concealment of bodies during the military dictatorship in Uruguay (1973-84). In Human Remains and Identification: Mass Violence, Genocide, and the 'Forensic Turn', (Eds, Anstett, Editor: Élisabeth \& Dreyfus, Editor: Jean-Marc) Manchester University Press, Manchester, pp. 83-97.

Mastrogiovanni, Federico. (2016) Ni vivos ni muertos: la desaparición forzada en

México como estrategia de terror. Debolsillo, México.

McSherry, J Patrice (2002) Tracking the origins of a state terror network: Operation Condor. Latin American Perspectives, 29, 38-60. 